\title{
Systemic manifestations of chronic hepatitis $C$ - results from a study performed in a rheumatology clinic
}

\author{
Elena-Sînziana Daia ${ }^{1,2^{*}}$, Viorel Văleanu1, Daniela Opriş ${ }^{1,2}$, Ruxandra Ionescu ${ }^{1,2}$ \\ From The 9th Edition of the Scientific Days of the National Institute for Infectious Diseases Prof Dr Matei Bals \\ Bucharest, Romania. 23-25 October 2013
}

\section{Background}

Hepatitis C Virus (HCV) infection is frequently associated with several extrahepatic manifestations (EHM) and sometimes the articular, cutaneous or endocrine complains are the ones that first refer the patient to the physician and reveal the underlying hepatic disease. Patients with HCV show a broad spectrum of rheumatic manifestations such as arthritis/arthralgia, sicca, vasculitis or fatigue. The aim of the study is to determine the prevalence of EHM and that of rheumatic-EHM in a group of HCV-infected patients admitted to an internal medicine and rheumatology department and to identify the associations between the clinical and biologic manifestations.

\section{Methods}

We performed a cross-sectional analysis of all cases of HCV-infected patients admitted to the "Sf. Maria" Clinical Hospital between January 2011 - June 2013. We assessed the patients regarding the articular, skin, xerostomia/xerophthalmia, hematologic, endocrine, neurological complaints and the biological abnormalities and verified the statistic correlation of the results. We used SPSS-program, Pearson correlation coefficient and $\mathrm{Hi}^{2}$ test of interdependency.

\section{Results}

The study included 112 patients with chronic HCV infection, with the median age of $61 \pm 11$ years. 67 (59.82\%) of these patients (of which 57 (85.07\%) females) had at least one EHM, the most frequent being arthritis/arthralgia in $29(25.89 \%)$ patients, type two diabetes mellitus in 17 (15.17\%), atherosclerosis in $11(9.82 \%)$ and depression in

\footnotetext{
* Correspondence: daia.sanziana@gmail.com

${ }^{1}$ Carol Davila University of Medicine and Pharmacy, Bucharest, Romania

Full list of author information is available at the end of the article
}

$10(8.92 \%)$ patients. Of the rheumatic-EMH, arthritis/ arthralgia were found in $29(25.89 \%)$ patients, sicca syndrome in $8(7.14 \%)$ and cryoglobulinemic vasculitis in 3 $(2.68 \%)$ patients. The rheumatoid factor was the immunologic abnormality mostly encountered, in 23 (76.67\%) patients. Rheumatoid arthritis was diagnosed in 36 (32.15\%) of the patients making the differential diagnosis with HCV-related arthritis difficult. Numerous EHM were found in patients with normal ALT levels.

\section{Conclusion}

Extrahepatic manifestations of HCV infection are frequently seen in the rheumatology practice. Clinicians should always think of a possible viral infection and a test for HCV should be performed in patients who present with these conditions, regardless of normal ALT levels. A multidisciplinary approach is required in order to assess and treat both the EHM and the underlying hepatic disease.

\section{Acknowledgement}

This paper is supported by the Sectoral Operational Programme Human Resources Development (SOP HRD) 2007-2013, financed from the European Social Fund and by the Romanian Government under the contract number POSDRU/107/1.5/S/82839.

Authors' details

${ }^{1}$ Carol Davila University of Medicine and Pharmacy, Bucharest, Romania. ${ }^{2}$ Internal Medicine and Rheumatology Department, "Sf. Maria" Clinical Hospital, Bucharest, Romania.

Published: 16 December 2013

doi:10.1186/1471-2334-13-S1-P55

Cite this article as: Daia et al:: Systemic manifestations of chronic hepatitis $C$ - results from a study performed in a rheumatology clinic. BMC Infectious Diseases 2013 13(Suppl 1):P55.
C Biomed Central

() 2013 Daia et al; licensee BioMed Central Ltd. This is an Open Access article distributed under the terms of the Creative Commons Attribution License (http://creativecommons.org/licenses/by/2.0), which permits unrestricted use, distribution, and reproduction in any medium, provided the original work is properly cited. 